\title{
SPACE IN COERCIVE POETRY. AUGUSTINE'S PSALM AGAINST THE DONATISTS AND HIS INTERPRETATION OF THE FEAR OF GOD IN ENARRATIONES IN PSALMOS
}

\author{
PAUl J. J. VAN GEEST ${ }^{*}$ \\ Tilburg University
}

\begin{abstract}
This contribution consists of two parts. The first part identifies Augustine's qualities as a mystagogue on the basis of the only poem he wrote that has been handed down: the Psalm against the Donatists. It shows that little is to be gained by studying Augustine as both poeta and mystagogue. Not his poetry itself, but his commentary on poetry as such reveals the transformative power that he ascribes to this genre. For this reason the second part examines Augustine's Enarrationes in psalmos. In this work, he makes explicit the transformative power that is contained in the 150 Psalms, which are both poetry and prayer. This part asks the question how Augustine articulates or heightens fear when the Psalmist in his dialogue with God 'compels' him to do this, as it were, by expressing fear of enemies or of the Last Judgement. He shows that he acknowledges that fear alone can lead to an unbalanced, and even a bad relationship with God. Fear should result in introspection and should be a guarantee against pride. That Augustine furthermore is not content to heighten the fear of God alone, but wants it to coincide with desire, joy, and hope, shows that he wishes to prevent any imbalance in the human who seeks a relationship with God. For Augustine, fear is necessary, but it is 'only' an ancilla of hope, joy, love, and desire. But as such, timor is indispensible. Fear causes attentiveness and carefulness: virtues that love presuppose and that also correlate with it. Nevertheless, love does not stand at the service of fear; for Augustine, it is the reverse.
\end{abstract}

KEY WORDS: Mystagogy, poetry, psalms, patristics, Augustine

\section{Introduction}

Augustine has not gone down in history as an author who sought to establish a transformation in his readers' hearts or attitude to life by writing poetry. On the contrary. It is true that Augustine's parenetic desire to change the behaviour of, and even effect a deeper transformation in, people who already shared his world view can be discerned in all of the books of his Confessions. It is also clear that he had the protreptic wish to effect a change of world view among those who did not yet share this world view. Thus it has been demon-

PAUL J. J. VAN GEEST (PhD 1996, Catholic Theological University of Utrecht) is professor of church history and historical theology at Tilburg University. Email: p.j.j.vangeest@tilburguniversity.edu. 
strated convincingly that he strove to initiate the Manicheans in the inscrutability of the human soul, and, as the books progress, also in the mystery of the inscrutability of God, Creator and Father (book XI), Son (book XII) and Holy Spirit (book XIII) (Kotzé 2004: 58ff; Bettetini 2015: 74-76). The Confessions therefore certainly show Augustine as a mystagogue. But this magisterial book is a work of Latin prose, of which Augustine was a master, and it does not establish his reputation as a poet.

Augustine does mention in the Confessions that he participated in his youth in poetry competitions, and he quotes three lines from a catechetical poem of praise of the Easter candle in classically shaped hexameters in The City of God (Confessiones 4.1; 4.3; De ciuitate Dei 15.22). He also composed an elegy in eight hexameters, an acrostic, for Naborius, a local martyr who fell victim to Donatist violence. This poem in particular demonstrates that he was familiar with classical and Christian poetry, to a greater degree even than his critique of poetry in Confessions 1.20-23 would suggest (Hunink 2005a: 88-91).

Augustine's poetry cannot match-either in quality or in quantity-his Confessions, The City of God, or his vast collection of sermons, Enarrationes in Psalmos, treatises on creation and other theological works. The fact that he produced one substantial work of poetry does not negate this contention. The Psalmus contra partem Donati consists of circa three hundred lines and has always been received in history as: 'an almost unpleasant little work ... that seems lacking in any stylistic pretension' (Hunink 2005a: 7).

The current contribution consists of two parts. The first will attempt to identify Augustine's mystagogical qualities on the basis of the Psalm against the Donatists. It will reveal that little is to be gained by studying Augustine as both poeta and mystagogue at the same time. Not his poetry, but his commentary on poetry demonstrates the transformative power that he ascribes to this genre. In the second part, therefore, I propose to examine his Enarrationes in Psalmos. It becomes evident there that he places great value on the transformative power of the Psalms, which are both poetry and prayer. This part asks the question how Augustine makes explicit or intensifies fear when the Psalmist in his dialogue with God 'compels' him to do so, for instance by articulating his fear of enemies or of the Last Judgement.

\section{Augustine's Psalm against the Donatists}

The Psalmus is Augustine's first work against Donatism. Augustine wrote it in 393, two years after his ordination to the priesthood. His bishop, Valerius, badly needed Augustine's support in the struggle against heretical movements such as the Donatists.

The Donatists themselves traced back their origins to the persecutions of Christians that occurred under the Emperor Diocletian (284-305). His improvement of the military, monetary, and administrative structures of the 
Roman empire led to restrictions on the rights of Christians, and, from 303 onwards, to the last and most serious wave of persecutions of Christians within his Empire. That year, he ordered that the holy books of Christianity had to be handed over to the civil authorities for destruction. ${ }^{1}$ Christians were required to demonstrate their loyalty to the emperor and the gods of the empire by performing the so-called thurificatio (purification). Many Christians submitted to the imperial command out of fear of death or loss of possessions. Christians who had handed over holy books were called traditores 'squanderers'. ${ }^{2}$ It was forbidden to have contact with them; re-admittance to the church was only possible after a long process of penance.

Because there were no publicly accessible lists of these traditores, it was unclear at the end of the persecution in 305 who had in fact been one and who had not. Nevertheless, seventy Numidian bishops declared the consecration of Caecilianus, who had been elected the primate of Africa in 311 or 312 in Carthage, null and void because one of the consecrating bishops was suspected of having been a traditor. Although Caecilianus had the backing of Constantine-the emperor wanted unity in his empire through unity in the Christian church-the Numidian bishops chose Majorinus as their primate. From 313 onwards, his charismatic successor Donatus succeeded in rallying the regional establishment to the church that bore his name. When an ecclesiastical court in Rome and an imperial synod in Arles (314) failed to restore unity, Constantine himself decided in favour of Caecilianus post episcopalia iudicia (cf. Epistula 88, 2-3; Epistula 105.8).

It was to no avail. Extremist armed circumcelliones even regarded Donatism as a nationalist movement against the emperor. In their struggle against the emperor they tortured and assassinated Catholic clerics and renegade Donatists, and carried out suicide killings (Augustine, Epistula 134, 2; c. Litt. Pet. II, 91, 201 et passim). Nor did the imperial commissary Macarius refrain from using violence in his attempts to compel the pars Donati to return to the Catholic church. Although the Emperor Constans issued a law in 347 that made unity with the Catholica compulsory, the schism between Donatists and Catholics became final around 360 (Codex Theodosianus XVI 6, 2). From that time on, the pars Donati developed its own theology of ministry and its own ecclesiology. These were distinct from their Catholic equivalents in that the Donatists traced their notion of holiness back to the idea that they were the successors of the martyrs who had refused to hand over the books-an idea that lacked historical evidence. In addition, just as in classical Roman religion, (1844: 673-784), Monceaux (1920: 311-328.329-333.335-339), and Tilley (2011). 
the Donatist bishops considered that the holiness of the community was effected through the performance of clearly defined rituals, which they derived from the purity laws in the Old Testament (c. ep. Parm. II, 7,12; Sermo 268, in PL 38, col. 1232-1234). Although there were exceptions, such as Tyconius, for most Donatists striving for holiness did not primarily involve personal transformation. One consequence was that they developed an ecclesiology based on strict opposition between the church and the world. Their church contained those who were integer, whole, on the basis of their second baptism; outside it were those who were profanus or adulter. Augustine's opposition to the Donatist view of the church and of humankind was based partly on the fact that it lacked a concept of personal transformation, just as he refused to accept the Donatist opinion that the efficaciousness of the sacraments was dependent on the ritually effected holiness and qualities of their minister. He emphasised that Christ was the auctor of the sacrament, and that the minister, however sinful, could not diminish the grace that it dispensed.

In 397, the Emperor Honorius harshly suppressed the rebellion led by Gildo, the Moorish comes Africae, as well as the circumcelliones, and other Donatists. Shortly afterwards, the Edict of unity (405), which declared that the laws against heresy also applied to the Donatists, disbanded their church and licensed civilian violence against them. Donatism nonetheless continued to retain influence in the countryside, even until after Augustine's lifetime. ${ }^{3}$

These things had yet to happen, however, when Augustine wrote his Psalmus in 393. It was his first work against the Donatists; his polemics against the Donatist bishops Petilianus and Parmenianus were to follow later. In his Retractationes, 'Re-treatments', two years before his death, he observed that he had written the Psalmus to inculcate the simple people with the truth about Donatism, qualifying it as a poem that really does not deserve the name of poetry. He admitted that he consciously refrained from following the metric forms which, according to the Roman view, determined the poetic quality of a poem. He also explained why: he did not want to be forced by the metre to use words that the ordinary people might not know (Retractationes 1.20).

He recounted in his Epistula 55.18 that the idea to write a kind of psalm had occurred to him after the Donatist Bishop Parmenianus's use of this literary form-a theological debate in the form of a popular poem-had been successful.

The poem consists of 297 lines and it has a refrain that is repeated after every stanza. This refrain, with which the text also begins, is part of a prologue of five lines, followed by 20 stanzas each consisting of 12 lines, and the first letters of each stanza together form the alphabet. This makes the poem an abecedarium, an alphabet poem. This feature makes it easy to learn it by heart. In his Re-treatments, Augustine mentioned, however, that he dropped 
the last letters and added an epilogue in which Mother Church addresses the Donatists (Retractationes 1.20).

The poem nonetheless also brings to mind associations with Psalm 119, the only Psalm in which each stanza also begins with a consecutive letter of the (Hebrew) alphabet. The effect of this on the reader is that a parallelism is created between the Psalmic praise of the Law of God and Augustine's case for being a Catholic. For more advanced readers, clerics for instance, this parallelism evoked by Augustine means that the Law of God can best be put into practice by being a Catholic, that is, by not being an adherent of Donatism.

Augustine was modest about his own poetic qualities; as Vincent Hunink has recently persuasively argued, he was in fact too modest. Hunink has pointed out that Augustine 'demonstrated a surprisingly poetic form' by dropping the tone in the middle of the line and making it rise again at the end by using end rhyme on '-e'. The vocabulary and syntax are admittedly simple: the text contains vulgar Latin elements, Augustine used the to quoque fallacy, and coarsely and vehemently called Caecilianus' opponents 'godless'; also 'his reasoning is not always very subtle' (Hunink 2005a: 17-18). Nonetheless his choice for an abecedary psalm following the Hebrew model, his rhetorical stylistic devices such as repetition, antithesis and anaphor, all testify to careful composition. Augustine's main concern was to have a form whose rhythmic structure made it suitable for recitation by singers. In addition to the lowering of the tone in the middle and the raising at the end of the line, and of the end rhyme on '-e', 'the text is really a miracle of regularity compared to normal Latin psalms. This is so because it unquestionably displays the tendency to have approximately sixteen, seventeen syllables, as well as the tendency to make the word accent resonate. When recited, it will therefore have sounded different, because it was slicker and 'faster' than normal psalms, undoubtedly to the audience's satisfaction' (Hunink 2005a: 25; Hunink 2005b: 95).

The nature of the transformation that Augustine seeks to effect in his Psalmus can be easily discerned from the refrain (the lines 1-2 and passim):

Omnes qui gaudetis de pace, modo uerum iudicate.

$$
\begin{aligned}
& \text { All you who find joy in peace, } \\
& \text { now judge what is truth. }
\end{aligned}
$$

The refrain does not expound a point of view, but contains a terse invitation to the reader to come to his own judgement on, and choice against Donatism, on the basis of the content of the stanzas that the refrain alternates with. At first sight, Augustine's goal appears to be nothing more than to achieve a change of insight through his psalmus. This is why the refrain consistently uses the second person plural. By also using the second person plural in the stanzas, Augustine shows that this choice is not a purely individual matter. 
The plural 'you' will have to arrive at the right judgement and make the right choice together.

But Augustine does more than this. He also wants to convince the Donatists that they belong to the pax Christi (line 4), which embodies the unity of the catholica. This is why Augustine uses the first person plural for the final words of the prologue: quaeramus hoc sine errore, which can best be translated as 'let us inquire without error'. The sine errore is ironic: while the Donatists regard themselves as being without error, Augustine presents his Psalmus as an inquiry without error. This first person plural at the start therefore evokes inclusivity between the author and the reader. The collectiveness which is the intended result of the Psalmus is therefore already conjured up in a literary way in the prologue. Even if a first person, either singular or plural, were to appear over and against the reader, the reader will know from the prologue that this is 'only' a rhetorical device, because the Psalmus begins with the inclusivity of the first person plural.

The conclusion of the Psalmus testifies to Augustine's objective of strengthening awareness among Donatists that they do not stand in isolation from the Catholics. In the epilogue, the first person plural has been replaced by a first person singular for the author's role. Augustine announces there that Mother Church (mater ecclesia, line 270) herself will address them. He addresses them as fratres. This form of address has been carefully prepared in the stanzas. First in the first line of the first stanza, where the word fratres is used in describing the confusion among the brothers. The word fratres then appears again in the first line of the E stanza in a quotation from Psalm 133:1 - it is good and delightful to live in unum, together, in unity, as fratres. Augustine thus uses inclusive language in the prologue and epilogue. Both Donatists and Catholics may deduce from this that they fundamentally belong to one and the same community. The literary inclusio reflects an existential one. The confrontation takes place inside the inclusio, partly through the second person plural that appears in the refrain; not the other way round.

In the Psalmus itself it is evident that Augustine, other than the refrain might suggest, is not only interested in effecting a noetic transformation. The theological metaphors, the account of the history of the schism, the reproach directed at the Donatists that they were book squanderers themselves, and Mother Church's call, are formulated so tersely that it seems the author was hoping for an emotive transformation as well as a noetic one.

In the prologue, Augustine indicates that he wants to find out who was responsible for destroying the peace of Christ, an act that results in death (lines 3-8). In the first stanza, the A stanza, he describes the church as the net that keeps the good fish and the bad fish together here on earth. He thinks it is wrong to tear the net, and for humans to arrogate to themselves the right to separate the good fish from the bad (lines 9-18; cf. Matthew 13:47-50). In

PERICHORESIS 14.2 (2016) 
the second stanza, 'those arrogant people, who call themselves just' (superbi qui iustos se dicunt esse, line 22), and who, moreover, accuse other people of being squanderers, even though they are guilty of this themselves, are accused of having destroyed the peace of Christ. He calls this a crime, because whereas the handing over of books might be defended as an act of fear (line 28), this schism in peace time cannot be the result of fear (lines 21-33). In the third stanza, he will call them false prophets, again tell them tersely that they are unable to prove who the squanderers of the books were, and state again that they might well have been squanderers themselves. Speaking untruths and schism are closely related, according to Augustine. Yet he concludes with the rhetorical question as to why peace was not preserved (lines 34-46).

In calmer tones, in the following stanza, the fifth, he weaves the history of the consecration of Caecilianus and the resulting schism into the image of the tearing of the net (lines 47-58 and 73-84; cf. lines 9-18), in order to trace back in the sixth stanza the lost unity of the fratres (Psalm 133:1) to the 'foolhardy claim' that Catholics handed over books; it is foolhardy because it cannot be proven. Again, however, he ends on a mildly worded supplication: this time to retain unity (lines 60-72).

In the seventh stanza, he reminds the audience for the third time of the lack of evidence, and he levels accusations at the circumcelliones. He suggests that the Donatists are tolerant of them (lines 86-97) through error or fear (errore vel timore, line 93).

In the following stanza, he revisits history and describes Constantine's mediation attempt in Rome and Donatus' initiative to introduce rebaptism (lines 99-111), and in the ninth stanza he blames the schism that has been ongoing since Donatus on Donatist pride, and not on the handing over of books, because in that case the schism would have had to have occurred at an earlier moment (lines 112-123).

In the tenth stanza, Augustine for the first time addresses 'the people from the crowds' tersely and directly, asking them to join his Catholic church because the emperor had decided in favour of this church (lines 125-136). In the eleventh stanza he issues an equally terse call to make peace, arguing that debates about the use of violence both by Macarius and by the circumcelliones, or about who had been a traditor, are unresolvable (lines 138-149). He leaves unmentioned that the Donatists were forced to go underground under Macarius.

It is strange that Augustine speaks extensively in the twelfth and thirteenth stanzas about the violence used by the circumcelliones and by Macarius (lines 151-162 and 164-175), while at the same time weaving into his narrative an entreaty for unity in true joy (nos amemus pacem Christi, gaudeamus in unitate, line 167). In contrived bitterness, he emphasises that it is not for humans to 
cut off the-allegedly-bad members from the Church, 'as those godless people did with their own altar there' (line 174).

In the three following stanzas, Augustine reminds the reader that the wheat and the chaff will not be separated until the last day (cf. Matthew 3:12). He was to explain this parable many times in future anti-Donatist writings to condemn the Donatists' eagerness to divide (lines 177-188, 190-201, and 203214). Even Judas was not excluded from the Last Supper (line 205). In the seventeenth and nineteenth stanza, Augustine denounces the Donatist practice of rebaptising people, as well as their assumption that the holiness of baptism is constituted by the ritually effected holiness of the minister (lines 216-227).

This seventeenth, R stanza, gives a clear example of Augustine's use of the stylistic device of the rhetorical question. The definition of a rhetorical question is that the answer is already clear, and that the person who is supposed to answer-in the Psalmus this is the reader-has no other option but to give the answer that the person who asks the question, Augustine, has in mind. Augustine uses this stylistic device to force the Donatists, as it were, to accept that Catholics and Donatists are already one (through baptism) and that the practise of rebaptising people is therefore invidious:

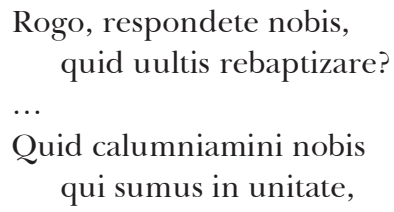

Answer my question. You want to rebaptise us. Why?

Why these calumnies against us while we are in unity?

In the eighteenth stanza, Augustine then stresses that the offshoot cut off from the stick represents those who are no longer rooted in apostolic succession. They are not viable (lines 239-241).

In the twentieth and last stanza, he returns to the images of the wheat and the chaff and the fishing net, and summarises once more his critique of rebaptism: 'you want to rebaptise Christians who are you own brothers!' (lines 255-266, especially 266).

In the epilogue, finally, Augustine announces first that the church will now speak herself; in her turn, Mother Church uses the same inclusive language that Augustine used, to express her sadness at the mutual accusations of the fratres and at the schism. She also expresses her incomprehension: while many in times past left her for fear of persecution, the Donatists are now rejecting her gifts at a time of peace. Her emotional narrative culminates in the question what it was that she did to them (sed ego quid uobis feci, line 288) and in the statement that she tolerates the bad so that they may be healed, or until the time of winnowing has come. It is striking that it is precisely Mother Church who intensifies fear towards the end of the epilogue.

PERICHORESIS 14.2 (2016) 
She calls the schismatics 'dead', as Augustine did in the prologue, and says she awaits Christ as Judge (lines 268-283). When he will ask her, she will speak (venturus est iudex noster; nos damus, exigit ille, line 297). The Psalmus thus ends on a menacing note.

The precise function of this fear, which is intensified in this threat, can be inferred from Augustine's interpretation of fear in the Enarrationes in Psalmos, and this brings us to the second part.

\section{Augustine's Appreciation of Poetry and of Timor}

As seen before, the value that Augustine ascribes to the genre of poetry as a mystagogue can be discovered not so much from his poetry itself, but from his commentary on a certain type of poetry, namely the Psalms. Precisely in his Enarrationes in psalmos he shows that he strongly values the transformative power that these forms of poetry and prayer possess. In this second part, I propose to examine how Augustine's appreciation of the Psalms as transformative poetry is expressed in the way he speaks explicitly of, or intensifies, fear whenever the Psalmist compels him to do this.

A few decades ago, Monique Vincent examined Augustine's view of petitionary prayer and of the prayer of praise in the Enarrationes in Psalmos. She demonstrated that in Augustine's view purity, isolation from the world, the acknowledgement of one's own paupertas, humility, hope, desire, and love, were the dispositions which humans ideally develop in their prayer in response to the love of God that they receive. She emphasised le caractère joyeux de sa prière. ${ }^{4}$ Her study of the vocabulary of prayer also highlighted this last point: the deprecatio, clamor or invocatio coincide with laetitia, excultatio, gaudium, jubilatio, eructatio. These basic emotions mean that prayer in the Psalms is mainly confessio laudis. ${ }^{5}$ That the connection between poetic prayer and desire in the Psalms has already been the subject of many studies can be explained by pointing to the fact that Augustine himself strongly emphasises this. ${ }^{6}$ Nonetheless, researchers have so far overlooked the fear of God as a transformative power expressed in the poetry of the Psalms, and this situation is unjustified. in Augustine's concept of prayer, the consciousness of one's own paupertas and humilitas coincide with an intensification of hope and desire, as well as with the realisation that love and all of the heart's other dispositions have been given as roots of this desire. She has convincingly demonstrated that 'confiteri means both confession of guilt and praise in Enarrationes, as it does in Confessions'.

See also Vincent (1991). In this work, she emphasises mainly that both 'deprecatio, clamor and invocatio belong both to prayer and to the confessio laudis and that this prayer moreover is characterised by laetitia, excultatio, gaudium, jubilatio, and eructatio'. 


\section{Augustine's Interpretation of Fear in the Psalms}

'Compelled' by the Psalmist, Augustine speaks a lot about fear in the Enarrationes. Timor and metus appear approximately three thousand times. A first remarkable feature is that Augustine spends a relatively great deal of time in the Enarrationes explaining the famous distinction between timor servilis and timor castus. It would take us too far afield here to discuss these forms of fear in depth. ${ }^{7}$ Suffice it to say that when Augustine interprets timor servilis and timor castus, he situates both forms of fear of God in the initial stages of a human's spiritual development and transformation.

His analysis of the structure of the Book of Psalms also indicates that Augustine places the fear that inspires conversion and penance at the beginning of the transformative process. In Enarratio in psalmum 150.3 he observes that the Psalmist speaks of penance in Psalm 50, of mercy and judgement in Psalm 100 , and of the praise of God in his saints in Psalm 150. These are precisely the phases that he himself identified as a mystagogue: the despising of one's sins through fear of the judgement precedes the justification that God in his mercy effects in the lives of those who, for some inscrutable reason, have been elected. ${ }^{8}$

The same is true for the Enarrationes where Augustine deals with the Donatists. Here, too, he wants fear to be heightened at the beginning of an individual formation process, but without being the dominant emotion thereafter. He was always inclined to advocate dialogue, but around 404-405 he condoned the threat of imperial violence against the Donatists, because they were causing disease to the Body of Christ, the global catholica, through their schism. To afford legitimacy to this fearful threat, he compares the (carrying out of the) imperial coercive measures to the painful acts that a doctor must perform to cure a patient. In almost the same way as he reminds the addressees of his letters of the possibility of imperial violence, he points in his Enarrationes to the Judgement, to cause the Donatists to return to the unity of the church by fanning the flames of their fear, this time the fear of God (en. Ps. 54.20).

To the Donatist bishop Vincent of Cartenna-whom he nonetheless called dilectissimo fratri-he wrote that fear of the law or of intervention by the state in itself is a useful instrument (Epistula 93.1.1; 93.5.18). He thought it would draws heavily on this publication.

8 The order in which people move towards eternal life contains the following stages according to Augustine: first they despise their sins, then they live good lives, and then they obtain eternal life. Yet he thinks that predestination is inscrutable. People are nonetheless called by the preaching of penance; justification however is effected through the call that is the work of divine mercy, and through fear of judgement. Enarrationes in Psalmos 150.3. 
pull the Donatists out of their comfort zone, compelling them to rethink their customs and attitude. But everything in this letter was intended to heighten fear as a prelude to a form of freedom in which the truth of the Catholic faith will be acknowledged even more clearly (Epistula 93.5.17). Fear should therefore be intensified to enforce a moment of conversion and reflection, which has as its final goal to initiate through fright a process of return to the Catholic church, ultimately to further peace and joy among the Donatists (Epistula 93.11.46).

Augustine's own words in the Enarrationes and in the letter to Vincentius shed an interesting light on the fear which he tries to heighten at the end of his Psalmus by reminding his readers of the Judge. In addition to convincing them noetically and emotively that they need to return to the unity of the church, the pax Christi, he also, briefly and at the end, wants to incite them to engage in self-evaluation. He uses a strong method for this: by heightening fear for the Judge. He does this in a way that is contrary to the supplications, in which he uses inclusive language. In 393, his mystagogical way, which leads through fear to trust and love, was yet in the early stages of its development.

The Enarrationes show that when Augustine intensifies the fear of God and his Judgement in the initial stage as a stimulus to bringing about self-evaluation, he paradoxically also plays down this fear. It is true that he emphasises in the Enarrationes that God's mercy in his Judgement of peoples and individuals also implies his justice. ${ }^{9}$ The consciousness of Christ's mercy in the tempus misericordiae does not relieve humans from the duty of exorcising their complacency by critical self-evaluation (en. Ps. 100.3.3). But Augustine remarks repeatedly and confidently that a self-judgement that takes account of one's own imperfection removes the grounds for God to issue a strict verdict at the Judgement: for the humble person who acknowledges his own imperfections, God will not prove to be iudex, but salvator (en. Ps. 66.6). He who now sets up a tribunal for himself in his own conscience, will on that day find Christ to be an advocate rather than a judge in the Judgement that follows death (en. Ps. 51.13). Personal conversion and remorse, according to Augustine, can prevent God's ira from growing (en. Ps. 100.3.3). He thinks fear is unnecessary if the law is written in a person's heart, causing it to be filled with remorse (en. Ps. 45.6). In this way, Augustine minimises fear in the sense that honest self-evaluation can undermine divine judgement, and in the sense that he regards compunctio as the goal to which fear must lead, and to nothing else.

He essentially accomplishes this playing down of fear of the Judgement by interpreting as poetic allegory those passages that speak of fear. As has been seen, he understands the tribunal of God primarily as humans' own examination of conscience, in which they ultimately turn to God in a confessio 
laudis (en. Ps. 49.28; 147; 66.6). He interprets God's hidden judgement in the same spirit as the pain and difficulties on earth that cause a person to come to reflection and conversion; this also positively affects the Final Judgement (en. Ps. 9.1). In the same way that he interprets Jesus' descent into hell as an allegory of Christ's teaching of those who are in darkness on earth in Epistula 164, he explains hell as the blindness of the soul that envelops the dying sinner in Enarratio in psalmum 6.6. ${ }^{10}$ His interpretation of the passage 'Turbatus est ab ira oculus meus' from Psalm 6:6 shows that his main objective in engaging in this allegorical interpretation is to expedite a confrontation of the sinner with himself rather than causing fear of judgement. He states that the sinner either fears the Judgement of which he is already experiencing the dreadful beginnings, or-and he clearly favours this interpretation-the eye of the sinner has been obscured by his own ira, which makes it impossible to view the inner sun, a poetic image for the wisdom of God.

In sum, just as with his interpretation of Christ's descent into hell in 1 Peter 3:18-21, Augustine's interpretation of certain Psalms does not mention the Judgement for the purpose of heightening fear for God. His goal is to intensify fear for the darkness within oneself. This-and not the Judgement itself-is what he tersely describes using allegorical interpretation. For Augustine, fearing God goes hand in hand with fearing one's own sins (cf. en. Ps. 18, sermo 2.14). However, by almost systematically using the Judgement as a metaphor for a judging agency within the human person and, moreover, by confirming that the Judgement will be positive if humans submit themselves to self-evaluation, Augustine assuages fear and consciously deprives himself of the possibility to increase the fear of God and his judgement. This characterises him as a mystagogue who reads poetry.

That Augustine is reluctant to let fear predominate in the Christian life is evident in the Enarrationes particularly from the fact that he says surprisingly frequently that fear should coincide with some other emotion or basic attitude. The Psalms contain polyphonic poetry. Thus Augustine argues for instance that it is necessary to fear God to remain alert and vigilant, but in the same sentence he also adds that joy is necessary to remain grateful towards God (en. Ps. 50.4). In different words: the fear of the awesome nature of the Creator should coincide with joy at his mercy (en. Ps. 32.3; 2.11). Fear and joy should keep each other in balance: fear alone leads to sombreness, but joy alone can cause unlimited irresponsibility.

More than once, Augustine suggests that the Psalmist would prefer that the praying person's disposition be determined by both fear and joy (en. Ps. 2.9). Translated to human life, this double voice means that human balance is highly important to Augustine. 
Augustine also mentions hope and fear in one breath as an expression of this poetic disposition. He thinks prophets' and evangelists' objective in heightening the fear of God is not just to keep people from focusing on those on earth who choose the easy way (en. Ps. 39.6). For Augustine, it is primarily hope in God that motivates the Christian to choose the narrow path (en. Ps. 39.7). Augustine recognises that certain Psalms articulate the fear that is tied up with the human condition and situation and that has characterised humankind from the beginning. But he emphasises that this voice is in harmony with the passages in the Psalms that express hope of resurrection (en. Ps. 29, sermo 2.16). In one particular prayer, Augustine increases the awareness that fear even evaporates in hope; he writes that he would fear God's justice and judgement if God's mercy and truth did not precede it, but that in fact he has nothing to fear because God's antecedent mercy has wiped away his sins. This is what God has already promised and brought to effect (en. Ps. 88, sermo 1.15).

He gives yet another slant to the relation between hope and fear when he tells his reader, in conformity with his 'theology of grace', that he should realise that the hope that he has in God-rather than fear of God-must be ascribed not to himself but to God (en. Ps. 55.6). He explains that fear and praise are part of the same dynamism in the human disposition in the Enarrationes by highlighting that the fear that is pure removes pride (en. Ps. 70.17), so that the praise of God may be pure (en. Ps. 21.1.24).

Augustine shows himself to be an exceptional mystagogue when he mentions fear of eternal death and love of God's promises as the basic emotions that cannot be separated, just as timor castus and amor castus. The fear of eternal death ideally coincides with love of God's promises (en. Ps. 64.16); fear of God on account of his justice ideally coincides with love of God on account of his mercy. ${ }^{11}$ In this way, Augustine portrays fear and desire not as opposites, but as complementary and sometimes even simultaneous. On the one hand he states that he himself is affected by fear of the Judgement and the coming of Christ, on the other hand he immediately adds that this is proof of an inconsistency, because if Christians live their lives well, they begin to desire Christ's coming. You cannot love someone whose coming you fear (en. Ps. 147.1).

\section{Augustine's Poetry as a Preparation for Medieval Poetry}

The poetic form of Augustine's Psalmus in the Patristic era inspired Fulgentius of Ruspe († 533) (Hunink 2005a: 24-25, Whelan 2014). In his Psalmus contra Wandalos Arrianos, 'Psalm against the Arian Vandals', Fulgentius carefully follows Augustine's pattern. This Psalmus, too, is an abecedary, and one 
including all twenty-three letters of the Latin alphabet, preceded by a prologue. He also uses end rhyme on '-e', and the Psalmus has a refrain.

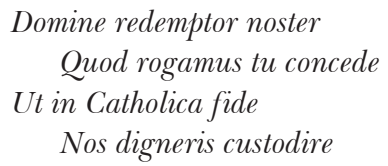

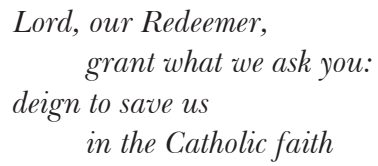

There is, however, one important difference with the refrain in Augustine's Psalmus. The refrain in the latter poem was addressed to the reader, thus compelling him or her to reflect and make the right choice. This particular sort of poetic involvement with the reader is lacking in the prayer formula of Fulgentius' refrain.

The fact that this kind of rhythmic poetry used by Augustine in his Psalmus can be exceptionally effective in winning the hearts and minds of an audience to embrace a certain image of God, humanity, or the world, was discovered primarily in the Middle Ages.

Leon Delaissé's research of an autograph of Thomas à Kempis from 1441, highly innovative at the time, has demonstrated that Thomas changed the rhythm of sentences-for instance by replacing words for the purpose of internal rhyme or by alternating dactyls and iambs-not so much out of love of the stylistic beauty of the Latin tongue (latinitas), but for catechetic reasons. Thus not only the four books of The Imitation of Christ, but also for example the Hortulus Rosarum were composed in a process of endless deletion and rewriting (Delaissé 1956). This way, Thomas' texts served the process of ruminatio, the meditative repetition of suitable pious phrases: a repetition aided by metre, internal rhyme, and end rhyme. This caused passages to resonate in the mind, so that their content formed and reformed not only thoughts, but ultimately the intended audience's entire attitude to life. In the Hortulus Rosarum for instance, Thomas writes:

Omnia sunt nulla: rex, papa, plumbea bulla (everything is nothing: king, pope, lead bull). ${ }^{12}$

In his book Thinking Fast and Slow, Nobel Prize winner Daniel Kahneman has presented empirical research into the way people become convinced of truths and untruths. He saw that the content of rhyming aphorisms was judged to be true more readily than that of non-rhyming aphorisms (Kahneman 2011: 95). This perhaps provides an unwitting explanation as to why The Imitation 
of Christ has been read, copied, translated, and printed so unimaginably frequently throughout the ages. In addition, Kahnemann makes predicative the insight that must have predominated with Augustine when he wrote his Psalm against the Donatists.

\section{Conclusion}

Augustine was no poeta, but with his Psalmus contra partem Donati he did compose a popular poem that uses various poetic stylistic devices to transform not only the thinking, but also the emotions of the ordinary faithful. The end rhyme on '-e', the form of an abecedary, the repetitive refrain: all these elements indicate that this, not stylistic beauty, was his primary goal. In addition, his casual but terse heightening of fear at the end is meant to induce a process of self-evaluation. Apart from in the Enarrationes and his letter to Vincentius, Augustine also indicates in his Praeceptum (6) that words which increase fear and invite self-reflection must always be followed by words of healing, because they might otherwise remain ineffective. This is a pivotal principle in his entire work, and it must always be kept in mind when interpreting the Psalmus. Fright must eventually bring about a return to the Catholic church, so that everyone may experience peace and joy.

As an interpreter of the Psalms, Augustine pays great attention to the poetic power of poems. Even when he is more or less 'compelled' by the poetic polyphony of the Psalms to dwell on the fear expressed by the Psalmist, he shows that he acknowledges that fear alone will lead to an unbalanced and even bad relationship with God. Fear serves to cause introspection and to remove pride. That Augustine is reluctant to heighten only fear, but wants fear to coincide with desire, joy, and hope, shows that he wants to prevent this imbalance in the human who is seeking a relationship with God. When speaking about the way in which God wishes to relate to humans, Augustine always emphasises God's mercy and closeness, even if the passage from the Psalm in question lends itself primarily to increasing fear of Judgement. Fear is necessary, according to Augustine, but it is 'only' an ancilla of hope, joy, and desire. But as such, timor is indispensable. It is the first phase in a process of transformation. He demonstrates precisely in the Enarrationes that he wants to form his readers into persons who know that pure love cannot exist in their lives without a fear that purifies it. Fear causes attentiveness and carefulness: virtues that love presupposes and that also correlate with it. Love, however, does not serve fear; it is quite the reverse.

\section{Bibliography}

Augustine (386-430) Epistulae.

Augustine (392-417) Enarrationes in Psalmos (en. Ps.).

Augustine (392-430) Sermones.

Augustine (393) Psalmus contra partem Donati. 
Augustine (397-400) Confessiones.

Augustine (400) Contra epistulam Parmeniani (c. ep. Parm.)

Augustine (400-3) Contra litteras Petiliani (c. Litt. Pet.).

Augustine (413-426/7) De ciuitate Dei.

Augustine (426-7) Retractationes.

Bettetini M (2015) Confessiones I: Die unbegreifliche Wirklichkeit der menschlichen Sehnsucht nach Gott. In Fischer N, Mayer C (eds) Confessiones des Augustinus von Hippo: Einfuehrung und Interpretation zu den dreizehn Buechern (Forschungen zur europaeischen Geistesgeschichte 1). Freiburg: Herder, pp. 133-164.

Delaissé LMJ (1956) Le manuscrit autographe de Thomas a Kempis et 'L'Imitation': Examen archéologique et édition diplomatique du Bruxellensis 5855-61 (Les publications de Scriptorium 2). Paris: Erasme.

van Geest P (1996) Thomas a Kempis (1379/80-1471): Een studie van zijn mensen godsbeeld. Kampen: Kok.

van Geest P (2016) 'Ergo sic time Dominum, ut speres in misericordia eius' (En. in ps. 146. 20): Augustine on the relationship between fear of God and personal prayer. In van Loon H, Op de Coul M (eds) The Early Christian Mystagogy of Prayer (Late Antique History and Religion 12). Leuven: Peeters. (in press)

van Geest P, Hunink V (2012) Met zachte hand: Augustinus over dwang in kerk en maatschappij [brief 185]. Budel: Damon.

Hunink V (2005a) Aurelius Augustinus, Psalm tegen de donatisten ['Psalmus contra partem Donati']. Budel: Damon.

Hunink V (2005b) Augustinus poeta. In van Geest P, van Oort H (eds) Augustiniana Neerlandica: Aspecten van de spiritualiteit van Augustinus. Leuven: Peeters, pp. 87-102.

Kahneman D (2011) Thinking fast and slow. New York: Farrar, Strauss and Giroux.

Kotzé A (2004) Augustine's Confessions: Communicative Purpose and Audience (Supplements to Vigiliae Christianae 71). Leiden: Brill.

Lancel S (1999) Donatista. In Mayer A, Chelius KH, Grote A (eds) AugustinusLexikon, volume 2, fasc. 3/4. Basel: Schwabe, kol. 606-622.

Monceaux P (1912-1923) Histoire littéraire de l'Afrique chrétienne, volumes 4-7. Paris: E. Leroux.

Optatus of Mileve (1844) Monumenta vetera ad Donatistarum historiam pertinentia, etc. (Migne PL 8).

Tilley M (2011) Redefining Donatism: Moving Forward. Augustinian Studies 42(1): 21-32.

Vincent M (1988) La prière selon saint Augustin d'après les Enarrationes in Psalmos. Nouvelle Revue Théologique 110(3): 371-402. 
Vincent M (1990) Saint Augustin: Maître de la prière d'après les Enarrationes in Psalmos (Théologie Historique 84). Paris: Beauchesne.

Vincent M (1991) Le vocabulaire de la prière chez saint Augustin. Augustiniana 41(4): 783-804.

Whelan R (2014) African Controversy: the Inheritance of the Donatist Schism in Vandal Africa. The Journal of Ecclesiastical History 65(3): 504-521. 